\title{
PENGEMBANGAN BUKU PENGAYAAN KIMIA SEBAGAI ALTERNATIF SUMBER BELAJAR MANDIRI PADA PEMBELAJARAN KIMIA TENTANG LARUTAN ELEKTROLIT DAN NONELEKTROLIT
}

\section{Development Of Chemical Enhancement Book As An Alternative Of Self- Learning Sources On Chemical Learning About Electrolite And Nonelectrolite Solutions}

\author{
Debby Hermawan, Novi Rahmawanti, Novrian Dony \\ Program Studi Pendidikan Kimia Fakultas Keguruan dan Ilmu Pendidikan Universitas \\ Islam Kalimantan (Uniska) Muhammad Arsyad Al Banjari, Banjarmasin \\ email: Debby_Hermawan@ymail.com
}

\begin{abstract}
Abstrak . Penelitian ini bertujuan untuk mengembangkan buku pengayaan kimia pada materi larutan elektrolit dan nonelektrolit. Buku pengayaan ini berfungsi sebagai penunjang belajar mandiri bagi siswa. Penelitian ini termasuk jenis penelitian pengembangan model Borg and Gaal tahap 1-5. Adapun sumber data berasal dari guru, siswa dan juga umum. Data akan dianalisis menggunakan metode kuantitatif deskriftif. Berdasarkan analisis data diperoleh kesimpulan bahwa kualitas buku pengayaan termasuk dalam kategori baik, dengan presentase keidealan mencapai $85,4 \%$. Buku ini juga dapat digunakan sebagai penunjang belajar mandiri juga ilmu pengetahuan bagi masyarakat umum.
\end{abstract}

Kata kunci: Buku pengayaan, elektrolit dan nonelektrolit

Abstract. This study aims to develop a chemical enrichment book on electrolyte and non-electrolyte solution materials. This enrichment book serves as a support for independent learning for students. This research is a type of development research Borg and Gaal model stages 1-5. The data sources come from teachers, students and also the general public. Data will be analyzed using descriptive quantitative methods. Based on the analysis of the data it was concluded that the quality of the enrichment books was included in the good category, with the percentage of ideals reaching $85.4 \%$. This book can also be used as a support for independent learning as well as science for the general public.

Keywords: Enrichment book, electrolit and nonelectrolit 


\section{PENDAHULUAN}

Belajar merupakan sebuah proses dalam memperoleh sebuah pengetahuan dan pengalaman. Belajar adalah hal yang sangat penting untuk dilakukan oleh setiap individu, karena hanya dengan belajar seseorang dapat memperoleh sebuah ilmu yang belum pernah didapatkan sebelumnya. Rebber (1988) mendefinisikan belajar sebagai proses memperoleh pengetahuan dan perubahan kemampuan. Belajar tidak hanya membutuhkan bimbingan dari seseorang seperti contohnya guru, namun belajar juga dapat dilakukan secara mandiri oleh individu tersebut. Oleh karena itu tidak hanya disekolah seseorang bisa belajar tapi dimana. Aktivitas belajar memerlukan sebuah media sebagai bahan belajar.

Di era teknologi saat ini media atau sumber belajar sangatlah banyak, namun masih terdapat banyak batasan dari sumber-sumber belajar tersebut seperti di pelosok desa yang tidak ada jaringan internet, perpustakaan terbatas, dan lainnya. Ketika media belajar seperti itu tidak bisa mencapai tempat-tempat tertentu maka dibuatlah sebuah media yang dapat menunjuang proses belajar seseorang seperti sebuah buku. Kimia adalah satu matapelajaran yang diajarkan pada tingkat SMA atau sederajat. Pembelajaran kimia adalah sebuah pembelajaran yang memerlukan peran aktif seorang guru dan murid sehingga akan memudahkan untuk dapat mengerti juga memahami pembelajaran yang terkesan sulit ini. Menurut Mahrus (2015) dalam Khairunnisa (2019), agar tujuan pembelajaran dapat tercapai dengan maksimal maka diperlukan media pembelajaran yang dapat mengaktifkan siswa. Dan untuk mengatasinya seorang guru dapat membuat sebuah media belajar berupa sebuah buku yang sedikit berbeda dari buku pelajaran pada umumnya, yaitu sebuah buku pengayaan. Buku pengayaan merupakan sebuah buku edukasi yang akan membantu siswa dalam mengerti sebuah pembelajaran, seperti materi yang dipilih oleh peneliti yaitu larutan elektrolit dan nonelektrolit. Pembuatan buku yang sedikit berbeda ini dipilih karena banyaknya siswa yang menilai buku- buku pelajaran terkesan monoton sehingga terkadang siswa tidak ingin berlama-lama membaca sebuah buku pelajaran. Dan berdasarkan hal inilah dibuat sebuah buku pengayaan yang dimana yang akan membantu mengembangkan proses berfikir, pengembangan kognitif, mengembangkan keterampilan, serta membentuk moral dan kultur positif(Depdiknas,2004). Seorang siswa dapat menggunakan buku pengayaan yang dibuat sebagai alternatif belajar mandiri sehingga pencapaian hasil belajar akan lebih terlihat

\section{METODE PENELITIAN}

Penelitian menggunakan sistem pengembangan prosedural bersifat deskriftif, menggariskan langkah-langkah atau prosedur yang harus diikuti dalam menghasilkan sebuah produk. Model penelitian ini diadaptasi dari Borg and Gall. Penelitian ini dilakukan di Kabupaten Barito timur dan Di SMA Barito Timur. Reviewer dari penelitian ini merupakan guru SMA/MA, murid SMA/MA, dan masyarakat umum, jumlah dari reviewer adalah 8 orang berdasarkan keahlian dan status sebagai reviewer.

\section{HASIL DAN PEMBAHASAN}

Berdasarkan penelitian didapatkan hasil penelitian berupa komponen penilaian kelayakan isi, kelayakan penyajian, dan kelayakan bahasa dan gambar seperti pada tabel 1 . 
Tabel 1. Komponen buku pengayaan

\begin{tabular}{c|c|c}
\hline Kelayakan isi & Kelayakan penyajian & $\begin{array}{c}\text { Kelayakan bahasa dan } \\
\text { gambar }\end{array}$ \\
\hline 34,25 & 28,5 & 35,5 \\
\hline
\end{tabular}

Berdasarkan penelitian dan penilaian dari para reviewer didapatkan data skor tiap komponen penilaian mulai dari kelayakan isi, kelayakan penyajian, dan kelayakan bahasa dan gambar secara berturut-turut adalah : 34,25, 28,5, dan 35,5, yang dimana data tersebut kemudian dikonversikan untuk mendapat skor ideal setiap komponen penilaian. Berdasarkan perhitungan kemudian didapatkan keidealan setiap komponen peniliaian adalah baik.

Persentase keidealan yang dihitung setelah menjumlahkan nila rata-rata keseluruhan komponen penilaian yang kemudian dibagi jumlah nilai tertinggi ideal keseluruhan komponen penilaian dan dikalikan $100 \%$ mendapatkan hasil 85,4\%, hal ini menunjukkan bahwa buku termasuk dalam kategori ideal dan layak untuk digunakan.

Persentase ideal buku pengayaan ini mencapai $85,4 \%$, Efektivitas yang masuk dalam kategori 1 dan angket penilaian Efesienitas buku dalam kategori Baik. Maka, menimbang reviewer bukan hanya dari kalangan sekolah (guru dan murid) tapi juga umum, buku ini efektif dan efesien digunakan sebagai bahan belajar mandiri bagi masyarakat umum tapi terutama bagi seorang pelajar.

\section{SIMPULAN}

Berdasarkan hasil penelitian dapat disimpulkan bahwa buku ini layak untuk digunakan sebagai media belajar mandiri bagi siswa dan juga masyarakat umum.

\section{DAFTAR RUJUKAN}

Depdiknas. (2004). Pedoman Merancang Sumber Belajar. Jakarta.

Khairunnisa, U., Akhyar, O., Wardhani, R, R, A, A, K. (2019). Pengembangan Media Wheels Question Pada Materi Sistem Koloid Untuk Meningkatkan Motivasi Belajar Siswa Kelas XI Di SMA Negeri 12 Banjarmasin. Dalton :Jurnal Pendidikan Kimia dan Ilmu Kimia. 2(1), 22-27.

Reber, A.S. (1988). The Penguin Dictionary of Psychology. Ringwood Victoria. Penguin Books Australia Ltd. 77 